\title{
PENGARUH TEMPERATUR AKTIVASI FISIKA TERHADAP KINERJA SUPERKAPASITOR BERBASIS ELEKTRODA KARBON DARI AMPAS SAGU
}

\author{
Erman Taer ${ }^{1}$, Zikri Al Rifani ${ }^{1, *}$, Rika Taslim ${ }^{2}$ \\ ${ }^{1}$ Jurusan Fisika, Fakultas Matematika dan Ilmu Pengetahuan Alam, \\ Universitas Riau \\ Simpang baru, Pekanbaru, 28293 \\ ${ }^{2}$ Jurusan Teknik Industri, \\ Universitas Islam Negeri Sultan Syarif Kasim, Pekanbaru, 28293 \\ *E-mail korespondensi: rialzikri@gmail.com
}

\begin{abstract}
The manufacture of activated carbon based on sago pulp as a super-capacitor cell electrode has been successfully performed. Preparation of activated carbon begins with heating of drying raw materials in the sun and followed by oven drying, pre-carbonization, milling, sieving, chemical activation with $2 M$ concentration $\mathrm{KOH}$ solution, pellet printing, carbonization at $600^{\circ} \mathrm{C}$ using $\mathrm{N}_{2}$ gas followed by physics activation with temperature variation of $700^{\circ} \mathrm{C} ; 750^{\circ} \mathrm{C} ; 800^{\circ} \mathrm{C} ; 850^{\circ} \mathrm{C} ; 900^{\circ} \mathrm{C}$ using water vapor and polishing of pellets are some of the steps that are followed. Carbon electrode density values for each sample of AC 700, AC 750, AC 800, AC 850, and AC 900 are $0,790 \mathrm{~g} / \mathrm{cm}^{3}, 0,791 \mathrm{~g} / \mathrm{cm}^{3}, 0,795 \mathrm{~g} / \mathrm{cm}^{3}, 0,760 \mathrm{~g} / \mathrm{cm}^{3}$, dan $0,754 \mathrm{~g} / \mathrm{cm}^{3}$. The SEM results show the shape of the particles formed unoccupied. EDX test results show the percentage of carbon reaches $90.13 \%$. The measurement of electrochemical properties performed by cyclic voltammetry method yielded an optimum specific capacitance of $106 \mathrm{~F} / \mathrm{g}$ obtained at a temperature of $750^{\circ} \mathrm{C}$.
\end{abstract}

Keywords: Activated Carbon, Sago Pulp, Electrode Carbon, variation of activation temperature, Supercapasitor.

\begin{abstract}
ABSTRAK
Pembuatan karbon aktif berbasis ampas sagu sebagai elektroda sel superkapasitor telah berhasil dilakukan. Pembuatan karbon aktif diawali dengan pemanasan mengeringkan bahan baku di bawah sinar matahari dan dilanjutkan dengan pengeringan oven, pra-karbonisasi, penggilingan, pengayakan, aktivasi kimia dengan larutan $\mathrm{KOH}$ konsentrasi $2 \mathrm{M}$, pencetakan pelet, karbonisasi pada suhu $600^{\circ} \mathrm{C}$ menggunakan gas N2 diikuti dengan aktivasi fisika dengan variasi suhu $700^{\circ} \mathrm{C} ; 750^{\circ} \mathrm{C} ; 800^{\circ} \mathrm{C} ; 850^{\circ} \mathrm{C} ; 900^{\circ} \mathrm{C}$ menggunakan uap air dan pemolesan pelet adalah beberapa langkah yang diikuti. Nilai densitas elektroda karbon untuk masing-masing

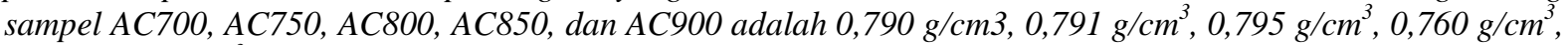
dan $0,754 \mathrm{~g} / \mathrm{cm}^{3}$. Hasil SEM menunjukkan bentuk partikel yang terbentuk tidak beraturan. Hasil uji EDX menunjukkan persentase karbon mencapai 90,13\%. Pengukuran sifat elektrokimia yang dilakukan dengan metode voltametri siklik menghasilkan kapasitansi spesifik optimum sebesar $1216 \mathrm{~F} / \mathrm{g}$ didapatkan pada suhu $750^{\circ} \mathrm{C}$.
\end{abstract}

Kata Kunci: Karbon aktif, ampas sagu, elektroda karbon, variasi temperatur aktivasi, superkapasitor.

\section{PENDAHULUAN}

Superkapasitor merupakan salah satu jenis kapasitor yang digunakan untuk menyimpan dan melepaskan energi. Penyimpanan energi terjadi melalui proses pembentukan pasangan ion dan elektron pada antarmuka antara elektroda dan elektrolit [1]. Komponen utama superkapasitor terdiri dari elektroda, elektrolit, separator dan pengumpul arus [2]. Elektroda superkapasitor dapat dikelompokkan menjadi karbon aktif, karbon nanotube [3], karbon aerogel [4], dan 
grapane[5]. Karbon aktif adalah bahan yang paling banyak digunakan. Salah satu bahan yang dapat dijadikan sebagai bahan asal dalam pembuatan karbon aktif adalah bahan biomasa. Penggunaan biomasa sebagai bahan asal dalam pembuatan karbon aktif memiliki keuntungan yaitu, harganya yang relatif murah, ketersediaan sumber yang berlimpah, dan juga mengurangi produksi limbah. Karbon aktif dapat dibuat dari berbagai bahan yang mempunyai kandungan karbon seperti kulit durian [6], batang pisang [7], ampas tebu [8], sebuk gergaji dari kayu karet [9], dan ampas sagu [10].

Ampas sagu merupakan limbah yang didapatkan pada proses pengolahan tepung sagu, dimana dalam proses tersebut dihasilkan limbah ikutan berupa kulit batang sekitar 17-25\% dan ampas sagu 75-83\% [11]. Ampas sagu memiliki kandungan bahan kering $86,4 \%$, protein kasar $2,1 \%$, lemak $1,8 \%$, serat kasar $20,3 \%$, abu $4,6 \%$, selulosa $36,3 \%$, hemiselulosa $14,6 \%$, lignin 9,7\%, dan silica 3,3\% [12]. Penelitian ini difokuskan untuk menentukan suhu aktivasi optimum dalam pembuatan karbon aktif dari ampas sagu menggunakan aktivasi uap air sebagai elektroda superkapasitor.

\section{METODE PENELITIAN}

Pembuatan karbon aktif dari ampas sagu dilakukan seperti metode yang pernah kami laporkan sebelumnya $[13,14]$. Proses pembuatan karbon aktif diawali dengan pengeringan sampel dibawah sinar matahari dan dilanjutkan menggunakan oven masing-masing selama 2 hari. Sampel hasil pengeringan diprakarbonisasi pada suhu $250{ }^{\circ} \mathrm{C}$ selama 2 jam, kemudian digiling menggunakan mortar dan ball milling. Sampel kemudian diayak dengan ayakan berukuran $53 \mu \mathrm{m}$ dan $38 \mu \mathrm{m}$. Aktivasi kimia dilakukan menggunakan aktivator $\mathrm{KOH} 2 \mathrm{M}$. Pencetakan pelet menggunakan hydraulic press pada tekanan 8 ton. Proses karbonisasi dimulai pada suhu $30{ }^{\circ} \mathrm{C}$ sampai $306{ }^{\circ} \mathrm{C}$, selanjutnya pada suhu $306{ }^{\circ} \mathrm{C}$ akan ditahan selama satu jam dan kemudian dilanjutkan mencapai suhu 600 ${ }^{\circ} \mathrm{C}$. Proses aktivasi fisika menggunakan uap $\mathrm{H}_{2} \mathrm{O}$ pada temperatur yang divariasikan yaitu $700{ }^{\circ} \mathrm{C}$,
$750{ }^{\circ} \mathrm{C}, 800{ }^{\circ} \mathrm{C}, 850{ }^{\circ} \mathrm{C}$, dan $900{ }^{\circ} \mathrm{C}$ selama 2 jam. Berdasarkan suhu aktivasi ini masingmasing variasi diberi kode sampel yaitu AC 700, AC 750, AC 800, AC 850, dan AC 900.

Karakterisasi elektroda karbon meliputi densitas, morfologi permukaan dan kandungan unsur menggunakan pengujian SEM dan EDX. Pengukuran kapasitansi spesifik superkapasitor dilakukan menggunakan metode cyclic voltrametry $(\mathrm{CV})$. Kapasitansi spesifik dihitung menggunakan persamaan berikut:

$$
C_{s}=\frac{\left(l_{\mathrm{L}}-l_{\mathrm{a}}\right)}{5 \times m}
$$

$\mathrm{C}_{\mathrm{sp}}$ adalah kapasitansi spesifik, Ic adalah arus charge, Id adalah arus discharge, $\mathrm{s}$ adalah scan rate dan $\mathrm{m}$ adalah massa elektroda.

\section{HASIL DAN PEMBAHASAN}

Hasil perhitungan densitas elektroda karbon sebelum dan setelah karbonisasi dan aktivasi ditunjukkan pada Gambar 1.

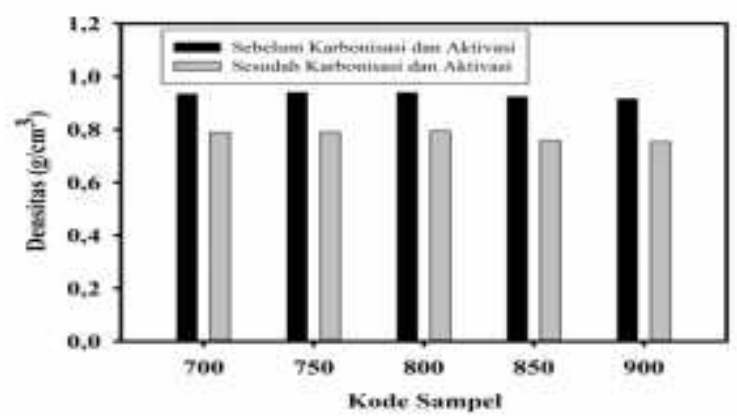

Gambar 1. Perbandingan nilai densitas elektroda karbon.

Gambar 1 menunjukkan nilai densitas sesudah karbonisasi dan aktivasi mengalami penurunan. Hal ini dikarenakan proses karbonisasi bertujuan menghilangkan unsurunsur lain selain karbon, sehingga densitas elektroda mengalami penurunan. Proses aktivasi juga menyebabkan penurunan densitas karena terjadi reaksi antara $\mathrm{H}_{2} \mathrm{O}$ dengan karbon sehingga terjadi pemutusan rantai karbon [15]. Pemutusan rantai karbon yang menyebabkan pembentukan pori baru yang menyebabkan penurunan densitas. Semakin tinggi suhu aktivasi yang diberikan semakin cepat reaksi $\mathrm{H}_{2} \mathrm{O}$ dengan 
karbon, semakin banyak rantai karbon yang terputuskan, semakin banyak pori yang terbentuk sehingga densitas yang dihasilkan akan semakin rendah. Nilai densitas untuk elektroda AC 700, AC 750, AC 800, AC 850 dan AC 900 masingmasing sebesar $0,790 \mathrm{~g} / \mathrm{cm}^{3}, 0,791 \mathrm{~g} / \mathrm{cm}^{3}, 0,795$ $\mathrm{g} / \mathrm{cm}^{3}, 0,760 \mathrm{~g} / \mathrm{cm}^{3}$, dan $0,754 \mathrm{~g} / \mathrm{cm}^{3}$

Pengujian SEM dilakukan untuk mengetahui morfologi permukaan sampel yang ditunjukkan pada Gambar 2.
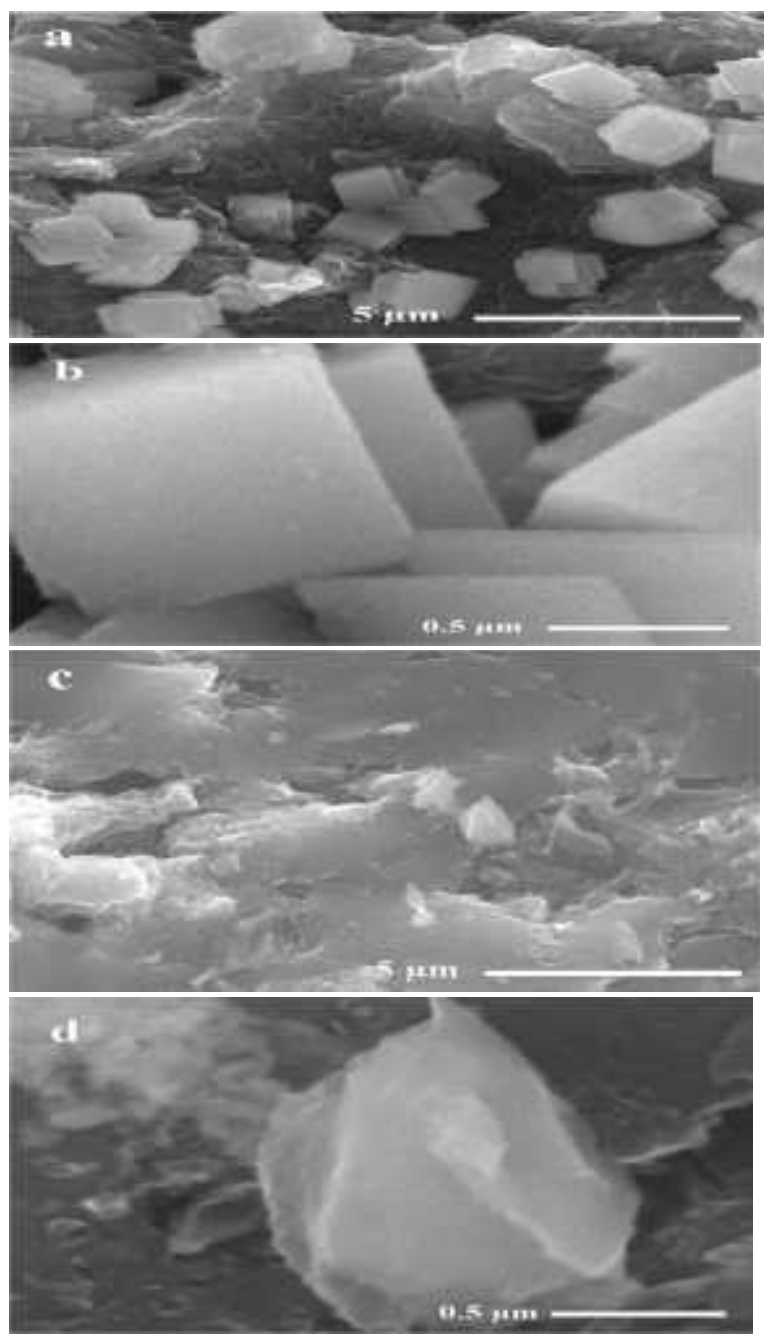

Gambar 2. Hasil SEM (a) AC750 Perbesaran 5000 kali, (b) AC750 Perbesaran 40000 kali, (c) AC850 Perbesaran 5000 kali, (d) AC850 Perbesaran 40000 kali.

Gambar 2 (a) menunjukkan hasil SEM elektroda karbon AC750 dengan perbesaran 5000 kali. Gambar tersebut memperlihatkan banyak partikel-partikel kecil yang terbentuk dan antar partikel tersebut terbentuk lubang kecil, hal ini diindikasikan dengan lubang-lubang kecil yang berwarna hitam. Gambar 2 (b) dengan perbesaran 40.000 kali menunjukkan bentuk partikel yang semakin jelas berbentuk balok. Bentuk partikel yang sama juga didapati pada penelitian yang dlapokan oleh arifin [16]. Gambar 2 (c) menunjukkan hasil SEM elektroda karbon AC 850 dengan perbesaran 5000 kali. Gambar tersebut menunjukkan bentuk permukaan yang padat dengan sedikit partikel dan pori yang belum terlihat jelas. Gambar 2 (d) dengan perbesaran 40.000 kali menunjukkan partikel berbentuk panjang tidak beraturan.

Pengujian EDX dilakukan untuk mengetahui kandungan unsur yang terkandung di dalam elektroda karbon. Hasil pengujian EDX ditampilkan pada Tabel 1.

Tabel 1. Kandungan unsur elektroda karbon ampas sagu.

\begin{tabular}{ccccc}
\hline \multirow{2}{*}{ Kandungan } & \multicolumn{2}{c}{ AC750 } & \multicolumn{2}{c}{ AC850 } \\
\cline { 2 - 5 } & Massa & Atom & Massa & Atom \\
& $\%$ & $\%$ & $\%$ & $\%$ \\
\hline $\mathrm{C}$ & 77.82 & 84.55 & 90.13 & 93.64 \\
$\mathrm{O}$ & 16.55 & 13.50 & 6.74 & 5.25 \\
$\mathrm{Si}$ & 0.76 & 0.35 & 0.73 & 0.32 \\
$\mathrm{Cl}$ & 0.07 & 0.03 & 0.53 & 0.19 \\
$\mathrm{~K}$ & 0.82 & 0.27 & 1.22 & 0.39 \\
$\mathrm{Ca}$ & 3.98 & 1.30 & 0.66 & 0.20 \\
\hline Total & \multicolumn{4}{c}{$100 \%$} \\
\hline \multicolumn{4}{c}{}
\end{tabular}

Tabel 1 menunjukkan kandungan unsur elekroda karbon terdiri dari karbon (C), oksigen $(\mathrm{O})$, silikon $(\mathrm{Si})$, klorin $(\mathrm{Cl})$, kalium $(\mathrm{K})$, dan kalsium (Ca). Unsur yang terdapat pada sampel elektroda dari ampas sagu didominasi oleh karbon. Kehadiran unsur oksigen disebabkan karena tidak sempurnanya karbonisasi atau dapat juga terjadi ikatan pada proses aktivasi [17]. Kandungan $\mathrm{Ca}$ dan $\mathrm{Si}$ yang terdapat pada elektroda karbon berasal dari kandungan kimia dalam sagu yang tidak terurai secara sempurna. Keberadaan unsur $\mathrm{K}$ berasal dari $\mathrm{KOH}$ yang digunakan saat aktivasi kimia. Unsur K tertinggal karena pencucian yang dilakukan tidak bersih.

Pengukuran nilai kapasitansi spesifik sel superkapasitor dilakukan dengan menggunakan metode CV. Hasil pengujian ditunjukkan oleh Gambar 3. 


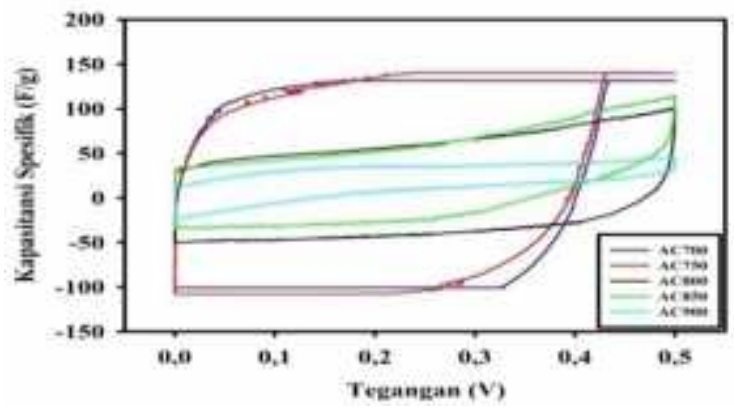

Gambar 3. Kurva cyclic voltammogram masingmasing sel superkapasitor dengan Laju Scan 1 $\mathrm{mV} / \mathrm{s}$.

Gambar 3 menunjukkan hubungan antar tegangan dan nilai kapasitansi spesifik. Luas daerah yang terbentuk pada kurva mengindikasikan besarnya kapasitansi spesifik, semakin besar kurva yang terbentuk maka semakin besar kapasitansi spesifik [18]. Nilai kapasitansi spesifik yang dihasilkan pada sel superkapasitor dengan elektroda AC 700, AC 750, AC 800, AC 850 dan AC 900 masingmasing sebesar 116 F/g, 121 F/g, 50 F/g, 41 F/g dan 11 F/g. Kapasitansi spesifik sel superkapasitor untuk elektroda AC 700 meningkat sebesar $5 \mathrm{~F} / \mathrm{g}$ pada AC 750 dipengaruhi oleh semakin cepatnya reaksi antara karbon dengan $\mathrm{H}_{2} \mathrm{O}$ sehingga semakin banyak rantai karbon yang terlepas [15], banyaknya rantai karbon yang terlepas akan menyebabkan banyak pori yang terbentuk sehingga semakin banyaknya pasangan ion dan elektron yang terbentuk dan akhirnya meningkatka kapasitansi. Sel superkapasitor AC 800, AC 850, dan AC 900 menunjukkan penurunan kapasitansi spesifik dikarenakan suhu aktivasi yang semakin tinggi akan merusak elektroda karbon disebabkan oleh oksidasi yang berlebihan [19].

\section{KESIMPULAN}

Suhu aktivasi menggunakan uap $\mathrm{H}_{2} \mathrm{O}$ opyimum dalam pembuatan elektroda karbon dari ampas sagu didapati pada suhu $750^{\circ} \mathrm{C}$ ditunjukkan oleh kapasitansi spesifik sel superkapasitor paling tinggi. Kapasitansi spesifik sel superkapasitor dengan elektroda AC 750 adalah sebesar 121 F/g

\section{UCAPAN TERIMA KASIH}

Terima kasih disampaikan kepada DRPM Kemenristekdikti yang telah mendanai penelitian ini melalui Penelitian Dasar Unggulan Perguruan Tinggi dengan judul Potensi Pemanfaatan Limbah Padat Perkotaan Sebagai Elektroda Superkasitor atas nama Dr. Erman Taer, M.Si Tahun 2018 dengan nomor kontrak: 360/UN.19.5.1.3/PP/2018

\section{REFERENSI}

1. Kotz, R. \& Carlen, M. (2000). Principles and applications of electrochemical capacitors. Electrochimica Acta, 45(15-16), 2483-2498.

2. Itagaki, M., Suzuki, S., Shitanda, I., Watanabe, K., \& Nakazawa, H. (2007). Impedance analysis of electrical double layer capacitor with transmission line model. J. Power Sources, 164, 415-424.

3. Niu, C., Sichel, E. K., Hoch, R., Moy, D., Tennent, H. (1997). High power electrochemical capacitors based on carbon nanotubes electrodes. Applied Physics Letters, 70.

4. Kim, C. Y., Jang, A. R., \& Cho, K. Y. (2012). Optimization of pore structuresand super capacitor properties of carbon aerogel electrodes. Asian Journal of Chemistry, 24.

5. Stoller, M. D., Park, S., Yanwu, Z., An, J., \& Ruoff, R. S. (2008). G raphene-based ultracapacitors. Nano Letters, 8.

6. Taer, E., Apriwandi, Sugianto, Yusriwandi, Mustika, W. S., Zulkifli, Taslim, R., Kurniasih, B., Agustino, \& Dewi, P. (2017). Comparative Study of $\mathrm{CO} 2$ and $\mathrm{H} 2 \mathrm{O}$ Activation in the Synthesis of Carbon Electrode for Supercapacitors. The $1 s t$ International Conference and Exhibition on Powder Technology Indonesia, AIP Conf. Proc. 1927, 030036-1-030036-6. 
7. Taer, E., Hartati, S. D., Sugianto, \& Taslim. R. (2016). Pengaruh variasi suhu aktivasi fisika terhadap sifat fisis dan elektrokimia elektroda Karbon superkapasitor dari Limbah kulit pisang. Jurnal fisika dan aplikasinya, 1(2), 2541-3392.

8. Taer, E., Iwantono, Manik, S. T., Taslim, R., Dahlan, D., \& Deraman, M. (2014). Preparation of Activated Carbon Monolith Electrodes from Sugarcane Bagasse by Physical and Physical-chemical Activation Process for Supercapacitor Application. Advanced Material Research, 896, 179-182.

9. Taer, E., Deraman, M., Taslim, R., \& Iwantono. (2013). Preparation of binderless activated carbon monolith from precarbonization rubber wood sawdust by controlling of carbonization and activation condition. Padjadjaran International Physics Symposium, 1554, 33-37.

10. Taer, E., Afrianda, A., Taslim, R., \& Malik, U. (2017). Pemanfaatan ampas sagu sebagai elektroda karbon Superkapasitor. Jurnal komunikasi Indonesia, p-ISSN:1412-2960; eISSN: 2579-521X.

11. Clatchey, M.. Manner, W., Harley, I., \& Elevitch, R. C. (2006). Metroxylon. Sp. Ecology papers Inc. London.

12. Sangaji, I. (2009), Mengoptimalkan Pemanfaatan Ampas Sagu Sebagai Pakan Ruminansia Melalui Biofermentasi dengan Jamur Tiram (Pleurotus ostreatus) dan Amoniasi. Disertasi, Institut Pertanian Bogor, Bogor.

13. Taer, E., Deraman, M., Thalib, I. A., Awitdrus, A., Hasmi, S. A., Umar A. A. (2011). Preparation of a Highly Prous Binderless Activated Carbon Monolith from Rubber Wood Saw Dust by a Multi Step Activation Process for Application in Supercapacitors. Int. Journal Electrochem. Sci., 6, 3301
14. Taer, E. (2009). Pembangunan Superkapasitor Menggunakan Elektroda Karbon. laporan penelitian FMIPA Universitas Riau, Pekanbaru.

15. Nurdiansah, H. \& Diah, S. (2013). Pengaruh Variasi Temperatur Karbonisasi dan Temperatur Aktivasi Fisika dari Elektroda Karbon Aktif Tempurung Kelapa dan Tempurung Kluwak Terhadap Nilai Kapasitansi Electric Double Layer Capacitor (EDLC). Jurnal Teknik Pomits, 2, 23373539 .

16. Aripin, H., Lestari, L., Ismail, D., \& Sabchevski, S. (2010). Sago Waste Based Activated Carbon Film as an Electrode Material for Electric Double Layer Capacitor. The Open Materials Science Journal, 4, 117-124.

17. Jankowski, H., Swiatkowski, A., \& Choma J. (1991). Active Carbon. Ellis Horwood, London. P., 17(31-40), 75-77.

18. Taer. E. (2015). Pembuatan dan karakterisasi sifat fisika green carbon paper tanpa perekat menggunakan limbah biomassa. Seminar nasional fisika, 6, 2476-9398.

19. Hartoyo, Hudaya, N., \& Fadli, (1990). Pembuatan arang aktif dari tempurung kelapa dan kayu bakau dengan cara aktivasi uap. Jurnal Penelitian Hasil Hutan, 8, 8-16. 